\title{
Т.В. Цимбал
}

\section{УКОРІНЕННЯ ЛЮДИНИ ЯК ГОЛОВНА ПРОБЛЕМА ЕКЗІСТЕНЦАЛЬНОГО ФІЛОСОФУВАННЯ СІМОНИ ВЕЙЛЬ}

Проблема життєвої укоріненості людини, на наш погляд, є однією 3 найважливіших у філософсько-антропологічному вивченні способу буття людини у світі. Тому зрозуміла увага філософів до феномену активно-діяльнісного самоствердження людини у життєвому просторі.

Діяльнісний підхід до вивчення людини грунтується на філософській парадигмі "буття-людина". Такий спосіб філософування орієнтує нас на цілісне розуміння людини та людської життєдіяльності в усій іiі універсальності та інтенціональності і дозволяє нам розглядати буття людини не тільки як єдність теоретичного і практичного відношень до дійсності, а як духовнопрактичне освоєння світу, завдяки якому і стає можлива самоідентифікація індивідів, самотворення та досягнення стану укоріненості у бутті.

Дана стаття $є$ намаганням знову повернутися до проблеми людини та людської життєдіяльності на основі аналізу філософського твору французької письменниці Сімони Вейль - "Укорінення".

Сімона Вейль (1909-1943) прожила коротке, але надзвичайно насичене, сповнене велетенськими труднощами та трагічними подіями, життя. Ї̈̈ твори позначені високою духовністю, проникливістю та виваженістю суджень.

"Укорінення" (1942 р.) було написане Сімоною Вейль, коли вона працювала у штабі французьких збройних сил у Лондоні, в трагічний для Європи час. Роздуми філософа відображують гостроту переживань людини, являють собою акт протистояння історичним трагедіям людства та відновлюють гостре протиріччя сили та справедливості, держави та окремої людини. 
Твір складається з трьох частин: "Потреби душі", "Позбавлення коріння" та "Укорінення", і має підзаголовок - "Пролог до Декларації обов'язків щодо людини".

Чому наголос зроблений саме на обов'язки людини?

Сімона Вейль виходить 3 того, що в тридцяті-сорокові роки тисячі емігрантів зіткнулися з проблемою відсутності прав людини, яка не має громадянства в тій чи іншій державі. Звідси філософ робить висновок, що поняття права $є$ "підлеглим та відносним". Право, яке не визнають інші, фактично не існує. Що ж до обов'язків, то вони не втрачають своєї сутності навіть не будучи визнаними ніким. Тому обов'язки є первинними відносно прав i, навіть, "одинока у всесвіті людина не мала б ніяких прав, проте, мала б обов'язки" [1. - С.3].

Ця думка є лише першим кроком до переосмислення філософом реальних потреб людини, на яких i грунтуються обов'язки.

Серед головних потреб людини С.Вейль виділяє потреби тіла, як то голод, спрага, втома, та чотирнадцять найважливіших потреб душі: порядок, свобода, послух, відповідальність, рівність, ієрархія, честь, покарання, свобода думки, безпека, ризик, приватна власність, колективна власність, правда.

Що стосується укорінення, то ця потреба є первинною і являється грунтом для інших потреб.

Укорінення, за Сімоною Вейль, - це "найважливіша та найменш визнана потреба людської душі, одна 3 тих, які найважче визначити" [1. - С.36].

Щоб запропонувати шляхи та способи укорінення, С.Вейль вважає за потрібне проаналізувати ситуації, коли людина втрачає або позбавляється коріння, тобто, знекорінюється.

По-перше, глобальне знекорінення відбувається під час воєнних завоювань, "тоді позбавлення коріння стає майже смертельною хворобою для поневолених народів" [1. - С.36]. Однак і самі завойовники, знекорінюючи інших, "підрізають" власні корені.

По-друге, до позбавлення коріння може вести економічне панування. Причому, головною "отрутою", що знекорінює людину в цьому випадку, є гроші та наймана праця як соціальне 
становище повністю залежне від грошей. Робітник, хоч і не втрачає географічних коренів, але морально позбавлений коріння, бо сутність його складають не духовні, особистісні сили, а здатність працювати, виступати "робочим матеріалом".

По-третє, до знекорінення веде сучасне розуміння освіти i культури в цілому, прірва між людьми освіченими та масами. Такий стан, на думку С.Вейль, $є$ результатом відділення культури від національної традиції в часи Ренесансу та занурення іiі в давньогрецьку традицію, яку згодом забули. А зв'язок 3 національним корінням так і не відновився. Як наслідок цього, "сформувалася культура, що розвинулася у досить вузькому колі, відділеному від світу, в атмосфері усамітненості, культура, яка орієнтована переважно на техніку й перебуває під ії впливом; відчутно забарвлена прагматизмом, вкрай роздроблена спеціалізацією, цілком позбавлена як контакту із цим світом, так і відкритості до іншого" [1. - С.38].

Освіта стала нічим іншим як нав'язуванням цієї штучної культури людині. Тому і потяг до культури йде не від серця, не $є$ наслідком духовних прагнень, а став "соціальним престижем".

3 іншого боку, Сімона Вейль впевнена, що культура, яка не спирається на минуле, яка втратила зв'язок 3 традицією втрачає підгрунтя, живлення, тим самим руйнуючи минуле, а це є "найтяжчий злочин". До того ж, наслідком знекорінення культури $€$ ідолопоклонство.

Виразним підтвердженням цієї тези є досвід німецького та радянського тоталітаризму у формах фашизму та більшовизму, коли самообман став нормативним принципом партійної пропаганди, охопивши усі суспільні сфери, призвівши до глобального знекорінення і "самозавоювання".

"Тотальний феномен держави, - пише С.Вейль, - полягає у своєрідному завоюванні, його здійснюють державні власті над народами, відповідальність за які вони несуть; здійснюють це таким чином, щоб народи не могли уникнути жодного лиха, яке неминуче супроводжує завоювання, - усе це для оволодіння найвигіднішою зброєю, аби уможливити завоювання зовнішні. Саме так сталося колись у Франції, не так давно - у Німеччині, не кажучи вже про Росію. 
Але розвиток держави виснажує країну. Держава поїдає моральну субстанцію країни, годується нею, товщає від неї, доки пожива не починає вичерпуватися, і це приводить державу до голодного знемагання..." [1. - С.103].

Тобто, знекорінення $є$ "найнебезпечнішою хворобою людських спільнот", бо знекорінена людина, за Сімоною Вейль, або впадає "у стан інерції душі, ... або кидається у діяльність, що завжди спрямована на позбавлення коренів тих, хто ще їх не втратив чи з ким це відбулося лише частково" [1. - С.39-40].

Причому, Сімона Вейль впевнена, що за поширення тоталітарного феномену, за триваюче "самопоїдання" повинні нести відповідальність не тільки творці названого політичного організму: кожен з громадян має міру власної відповідальності за самозавоювання. Таким чином, філософ впритул підходить до проблем сучасної комунікативної етики або етики відповідальності.

Важливі думки з окресленої проблеми висловив представник Мадридської школи Х.Ортега-і-Гассет. Розмірковуючи про кризу, що охопила Західну Європу на початку XX століття, філософ приходить до висновку: криза настає тоді, коли світ та культура попередніх поколінь втрачає свою значущість і людина залишається "без світу", тобто, без коріння. Криза отримує у Ортеги-іГассета назву - "повстання мас", де "маса - це безліч людей без особливих позитивних якостей. ...Маса - це середня, пересічна людина. ...це той, ...хто відчуває, що він - такий самий як всі інші, і при цьому зовсім не засмучений цим, напроти, щасливий відчувати себе таким як усі" [2. - С.120-121].

Тобто, на наш погляд, "людина-маса", що пливе за течією, це і є знекорінена людина, яка протиставляється філософом людині-індивідуальності, духовно суверенній та самоідентифікованій, людині обраній.

Найкращою рисою людини-індивідуальності Ортега-і-Гассет вважає ії духовну вищість та опертя на грунтовні норми культури, на правду, а не на силу. Принцип "сила замість права", за Ортегою, є симптомом політичної та культурної кризи Європи, що погрожує згубити європейську цивілізацію. 
Обрана ж людина, що сама вибирає справжнє життя, тобто, є обраною самою собою, вимоглива до себе більше ніж до інших, діє вільно та відповідально, може визначитися самостійно щодо заборон, обмежень власного свавілля. Саме на моральних нормах, як вважає філософ, і грунтується справжня демократія.

На жаль, 3 часів Просвітництва багатьма мислителями підтримувалась думка про те, що свобода - це відсутність зовнішніх обмежень та заборон. Але, якщо людина не має обмежень внутрішніх, то зняття зовнішніх переростає в свавілля індивідуальних бажань, що за Ортегою-і-Гассетом, і є одним з визначень людини-маси.

Яким же чином втрачається відчуття зовнішніх кордонів?

Філософ підкреслює, що від зовнішніх обмежень та від життєвих труднощів, які були породжені злиднями і важкою працею та заміняли самообмеження, прищеплені лише обмеженій освіченій меншості, маси людей звільнилися завдяки технічним та економічним досягненням.

На нашу думку, до втрати обмежень приводять не тільки названі Ортегою-і-Гасетом явища, а, перш за все, втрата культурної традиції, певних норм, звичаїв, цінностей, у тому числі і релігійних, тобто, "культурне знекорінення", а також відсутність власної відповідальності за вчинки, дії, думки, бажання сховатися у натовпі.

Думки Ортеги-і-Гасета є певним продовженням роздумів філософа-екзистенціаліста М.Хайдеггера про протилежність справжнього існування людини та безособового "das Man".

Людина, за М.Хайдеггером, є унікальною істотою, що створює саму себе, трансформуючи своє існування у сутність, несучи відповідальність за усе, що відбувається з нею та навколо неї. Але в процесі спільного буття ця неповторність втрачається, нівелюється і люди перетворюються на одиниці "натовпу". Тоді, з одного боку, для людини зникає суперечність між бажаним та дійсним, невпевненість, тривога, страх, людина звільняється від необхідності робити вибір, від відповідальності за вчинки (бо так роблять усі). 3 іншого боку, втративши унікальність та обравши "несправжнє буття", людина попадає під владу "іншого", 
під владу "das Man", що веде до вирівнювання відмінностей і "втрати власного існування".

Головна проблема в даній ситуації полягає в тому, що суспільство, як вважає М.Хайдеггер, зацікавлене в існуванні саме однакових, безпроблемних, не потребуючих самореалізації людей. Проте, існує "справжнє буття", детерміноване вільним вибором кожною людиною себе, свого власного шляху та бажаного суспільства. Таке протиріччя між людиною та суспільством і проявляється як відчуження, синдром масовості та знекорінення.

Розв'язання цього протиріччя, як вважають філософиекзистенціалісти, можливе двома шляхами. Перший з них, пасивний, передбачає звертання до Бога як джерела віри, духовності, що надає людині сили та надії. Другий шлях - складний та неоднозначний. Основою його є бунт як своєрідна форма виявлення протиріччя між людиною та формою суспільного устрою, коли людина захищає себе не такою, якою вона повинна бути чи хоче бути, а такою, яка вона $є$ насправді. В цьому, як вважає А.Камю, полягає позитивність бунту, який "відкриває в людині те, за що завжди треба боротися" [3. - С.132].

Таким чином, бунт, за А.Камю, це прагнення до справжнього життя, пошук сенсу життя, тобто, є одним 3 шляхів життєвого укорінення людини.

Проблему знекорінення людини розглядали і представники Франкфуртської школи (Т.Адорно, Е.Фромм, Г.Маркузе, М.Хоркхаймер та інші), досліджуючи, насамперед, суперечності між типом соціальної структури і змістом глибинних диспозицій особистості, іiі емоційної структури. Знекорінена людина - це i "авторитарна особистість" Т.Адорно та М.Хоркхаймера, і людина, що втікає від свободи" Е.Фромма, і "одномірна" людина Г.Маркузе.

Розглядаючи проблему пошуку шляхів життєвого укорінення людини, Сімона Вейль спирається перш за все на доробок європейської екзистенціальної філософії та на власний досвід. (Зауважимо, що, оскільки праця "Укорінення" залишилася незавершеною, філософ досліджує лише два з них).

Людина, на думку Сімони Вейль, укорінюється "через реальну, активну, природну участь в існуванні спільноти, яка збері- 
гає живими деякі скарби минулого й деякі передчуття майбутнього. Ця участь природна - тобто вона зумовлена автоматично місцем народження, професією, оточенням. Кожна людина потребує багато коренів. Вона потребує того, щоб сприймати майже всю сукупність морального, інтелектуального, духовного життя через посередництво тих кіл, у які вона природно входить" [1. - С.36].

Дійсно, як показує суспільна практика, особистість складається з різноманітних ідентичностей та ролей - родинної, територіальної, релігійної, етнічної та інших. І вплив цих кіл, за С.Вейль, життєво важливий не як зовнішній внесок, а як "стимул", що робить життя людини наповненим, інтенсивним.

Виходячи 3 цього, філософ окреслює перший шлях або спосіб укорінення - це освіта та самоосвіта, яка пробуджує "рушійні сили" людини. "Ніяка дія, - пише Сімона Вейль, - не відбувається за відсутності рушійних сил, спроможних постачати їй необхідну енергію" [1. - С. 150].

Причому, головним змістом освіти повинно стати вивчення історії та життєвого досвіду рідного народу, що забезпечує найбільш суттєву для кожної особистості етнічну або культурну ідентифікацію, тим самим відкриваючи шлях до самопізнання та уможливлюючи укорінення людини в світ національної культури. Повернувшись до національного минулого, людина відкриває для себе свою справжню природу, духовність, автентичний досвід буття та, можливо, подальшу долю.

Наголосимо, що певні традиції, обряди, звичаї, предмети матеріальної культури, а також історичні події, героїв та цінності етнічної культури потрібно вивчати не відсторонено, а включаючи безпосередньо в життєдіяльність особистості. Тільки так історія зможе передати прийдешнім поколінням не тільки доброчинність предків, а й їх власні права та обов'язки.

Другий шлях життєвого укорінення людини, за Сімоною Вейль, - це нова організація фізичної праці, що повинна бути "духовним центром" впорядкованого громадського життя. Такі зміни будуть можливими тільки тоді, коли фізична праця не буде насильницькою щодо людини, не буде націлена лише на результат, а й сам процес праці стане насолодою для працівника. 
Схожі думки щодо життєвого укорінення людини зустрічаємо у класика вітчизняної філософії Григорія Сковороди в роздумах про "сродність". За Г.Сковородою, природна, "сродна" праця є одночасно потребою тіла та потребою духу, тому що приносить задоволення та насолоду. Природна "сродність" надихає на відшукання гідних людини шляхів та засобів задоволення потреб. Таким чином, найкращим серед інших шляхів та засобів життєвої укоріненості людської особистості є "сродна праця", що приносить людині насолоду не тільки своїми результатами, а й самим процесом діяльності. Характеризуючи таку працю, Г.Сковорода вживає слова "забава", "свято", тому що "сродний труд" - це не тільки фізичні зусилля, а й активність духу та думки, прямування по шляху пізнання. Тобто, "сродна праця", за Г.Сковородою, є перш за все не засобом, а метою та сенсом життя.

"Сродна праця" - це процес духовно-практичного освоєння світу, "духовна діяльність, що протікає за алгоритмами практичних дій" [4. - С.72]. Це олюднена праця, яка несе в собі позитивні, конструктивні сили, яка допомагає людині здобути сутнісні сили та реалізувати їх, праця, в процесі якої "стверджується спорідненість людини з усім сущим" [4. - С.73], i, в той же час, зміцнюється індивідуальність, неповторність, свобода та моральна суверенність особистості.

Таким чином, короткий аналіз змісту концепції життєвого укорінення людини Сімони Вейль $є$ підставою для певних висновків, а саме:

1. Ця концепція є синтезом позитивних аспектів філософських вчень різного спрямування та світоглядної орієнтації. Саме вони $є$ її теоретичними джерелами та передтечею;

2. Методологічним підгрунтям концепції укорінення $\epsilon$ розвинута в ідеалізмі та марксизмі ідея людської активності, творчості, діяльності та самодіяльності, що і містить у собі укорінення як цілепокладання та цілереалізацію, сенс життя та свободу особистості;

3. Зважаючи на загальні положення екзистенціальної антропології, об'єктивний світ стосовно людини у концепції укорінення С.Вейль виступає лише засобом і не є самоцінним на 
відміну від самоцінності людини стосовно світу. Вона самоцінна своєю суб'єктивністю і своїм призначенням до самореалізації;

4. С.Вейль розділяе такий важливий принцип сучасної філософської антропології в розумінні сутності людини (а укорінення, на наш погляд, синонім сутності людини), який сформулював німецький антрополог О.Больнов. "Сутність людини" - то питання, яке завжди "відкрите для нових неочікуваних і незавбачуваних відповідей" [5. - С.110]. А отже, укорінення людини у життя - це процес принципової незавершеності, це прямування до належного, бажаного через можливе.

\section{ЛIТЕРАТУРА}

1. Вейль Сімона. Укорінення. Лист до клірика. - К., 1998. - 198 с.

2. Ортега-и-Гассет X. Восстание масс // Вопросы философии. - М., 1989, №3. - C.119-154.

3. Камю А. Бунтующий человек // Философия. Политика. Искусство. M., $1990 .-415$ c.

4. Крымский С.Б. Философия как путь человечности и надежды. - К., 2000. -308 c.

5. Больнов О. Філософська антропологія та іï методичні принципи // Сучасна зарубіжна філософія. Хрестоматія. - К., 1996. - С.96-111.

6. Сковорода Г. Пізнай в собі людину. - Львів: Світ, 1995. -528 с. 